\title{
obre o domínio da natureza na filosofia da história de Theodor W. Adorno: uma questão para a educaçã̃o
}

Jaison José Bassani

Alexandre Fernandez Vaz

Universidade Federal de Santa Catarina

\section{Introdução}

O presente trabalho tem como objetivo apresentar elementos da concepção de domínio da natureza na filosofia da história de Theodor W. Adorno e, a partir deles, pensar algumas questões para educação, em geral, e a educação do corpo, em específico. A referência fundamental do estudo é a clássica obra escrita com Max Horkheimer durante a década de 1940, Dialética do esclarecimento. Seguindo o rastro do pensamento dos autores, procuramos mostrar como o conflito do homem com a natureza simultaneamente expressa e produz a tendência de dominação da própria natureza, o que, por sua vez, se prolonga na dominação do homem pelo homem. 
O fio condutor da análise, como uma espécie de roteiro metodológico, é, no entanto, um texto menos conhecido no contexto brasileiro, fruto de uma conferência proferida por Adorno em 1932: A ideia de história natural (Adorno, 2003, p. 588-622; 1991, p. 103-134).

Ao tomarmos esse texto como um fio condutor da exposição que segue, buscamos uma porta de entrada à filosofia de Adorno por meio de uma obra mais breve, mas que contém destilados muitos dos problemas e questões levantados em seus demais trabalhos, considerando-a uma espécie de índice por meio do qual é possível acessar os temas mais diretamente relacionados à problemática do domínio da natureza na filosofia da história. Nesse texto, como indica Duarte (1993, p. 58), podemos rastrear importantes pressupostos da concepção de domínio da natureza que reaparecerá posteriormente, com todas as suas nuanças, na obra escrita com Horkheimer. Para Buck-Morss (1981, p. 132), não apenas no que se refere à noção de domínio da natureza, mas a Dialética do esclarecimento como um todo pode ser lida como a efetivação da ideia de história natural expressa por Adorno já naquele trabalho de 1932.

No texto-conferência, encontramos um conceito que representa elemento-chave no pensamento e no método de Adorno, e que constitui o ponto fulcral de nossa investigação. Trata-se do conceito de segunda natureza (zweite Natur). Tal categoria, como o próprio Adorno esclarece, e conforme se verá nas próximas páginas, constitui fundamento essencial da concepção de história natural, no sentido da superação da antítese habitualmente atribuída ao embate história e natureza.
Para cumprir o objetivo proposto, apresentamos, na primeira parte do trabalho, como Adorno compreende o fundo duplo dos conceitos de história e natureza. Logo após, expomos o núcleo-chave da filosofia da história de Adorno: a crítica à repetição do sempre-igual (Immergleichen), tema que, como veremos, é de forte inspiração benjaminiana. $\mathrm{Na}$ terceira parte, concentramo-nos no conceito de segunda natureza. Por fim, a título de nota final, exploramos algumas consequências da concepção de domínio da natureza na filosofia de Adorno para o campo educacional, em comentário sobre a relação entre corpo, técnica e produção da consciência reificada.

\section{Sobre o duplo caráter dos conceitos de história e natureza em Adorno}

O conceito de domínio da natureza, elemento fundamental tanto na concepção de história e progresso, quanto nas ideias sobre arte, cultura e filosofia de Theodor W. Adorno, tem sua formulação mais expressiva naquela que é a obra-chave do pensamento frankfurtiano: Dialética do esclarecimento, livro escrito a quatro mãos com Max Horkheimer e publicado pela primeira vez na metade dos anos de 1940 (Horkheimer; Adorno, 1985, 2003). Na crítica radical ao processo imemorial de esclarecimento (Aufklärung), a tese central defendida pelos autores é a de que, no percurso da civilização - no qual a repressão à natureza e a produção da subjetividade são constituintes e decorrências -, a passagem do estágio do mito para o do esclarecimento é produtora da regressão a um novo estágio mitológico, cujo conteúdo será ainda a dominação e a barbárie. 
O tema do domínio da natureza está presente com maior ou menor força desde os trabalhos da juventude de Adorno até as obras de sua maturidade intelectual. Frequentes, embora por vezes de forma menos explícita, as passagens nas quais a temática aparece mostram as preocupações do autor, já desde o primeiro terço do século passado, com as relações perversas entre o humano e a natureza, e com o esforço sem limites do primeiro para dominar e operacionalizar a si mesmo e o seu entorno. Tanto em obras escritas anteriormente ao período de redação da Dialética do esclarecimento, quanto naquelas da mesma época ou preparadas em momento posterior ao de sua publicação, ${ }^{1}$ podemos encontrar claras referências à concepção de uma "dialética do esclarecimento" nesse processo, segundo o qual, como dito anteriormente, o controle e a manipulação da natureza, condições necessárias para a civilização, se prolongam na dominação do homem pelo homem, e de cada indivíduo sobre si mesmo.

No que se refere aos textos da juventude de Adorno, destaca-se especialmente, dentro dos objetivos desta investigação, a conferência "A ideia de história natural" (Adorno, 1991, p. 103134; 2003, p. 588-622). Ela representa a contribuição para a conhecida "Discussão de Frankfurt", o debate sobre o historicismo que ocorria na universidade daquela cidade e do qual já haviam participado, entre outros, Max Scheler e Karl Mannheim (Buck-Morss, 1981, p. 119). O problema que se coloca para Adorno é o da fundamentação filosófica

1 Por exemplo, Adorno (1993, p. 209; 2003, 2127-2128, 8407 e 8431-8432; 1995b, p. 29 e 45). de um conceito de história natural capaz de permitir a superação da oposição tradicional entre os de história e natureza (Adorno, 1991, p. 104; 2003, p. 589). Portanto, como ele mesmo declara, não se trata de entender tal conceito "[...] en un sentido precientífico tradicional, ni siquiera de historia de la naturaleza, al modo en que la naturaleza es el objeto de las ciencias de la naturaleza". Ao mesmo tempo, complementa Adorno, esses dois conceitos não são entendidos "[...] como definiciones de esencia de una validez definitiva, sino que persigo el propósito de llevar tales conceptos hasta un punto en el que queden superados en su pura separación" (Adorno, 1991, p. 104; 2003, p. 589).

Conforme afirma Buck-Morss (1981, p. 112-122), o próprio título da conferência assinala o caráter dialético da abordagem de Adorno, expondo o seu entendimento em relação aos dois conceitos e, sobretudo, indicando a forma como ele os emprega em seus escritos (inclusive nos da maturidade intelectual): como conceitos cognitivos, ferramentas críticas para a compreensão e desmistificação da realidade. Ao mesmo tempo, cada conceito representaria a chave para a desmistificação e o entendimento do outro:

La naturaleza daba la clave para exponer la no identidad entre el concepto de historia (como idea regulativa) y la realidad histórica, del mismo modo que la historia proporcionaba la clave para desmitificar la naturaleza. Adorno sostenía que la historia real pasada no era idéntica al concepto de historia (como progreso racional) a causa de la naturaleza material a la que violentaba. 
Del mismo modo, los fenómenos "naturales" del presente no eran idénticos al concepto de naturaleza (como realidad esencial o verdad), porque [...] habían sido históricamente producidos. (Buck-Morss, 1981, p. 112-113, grifos do original).

Ao insistir na imbricação entre história e natureza, mais especificamente na inter-relação dialética, na não identidade e, no entanto, na mútua determinação desses dois conceitos, Adorno recusa-se a conceder-lhes-em oposição à ontologia heideggeriana, mas também a certa tradição hegeliano-marxista, representada especialmente por Lukács - o estatuto de princípio ontológico (Buck-Morss, 1981, p. 113; Jay, 1988, p. 98). Para Adorno, a partir do momento em que determinada teoria estabelece a história ou a natureza como premissa ontológica, perde-se, com isso, como aponta Buck-Morss (1981, p. 122-123), os significados multidimensionais de cada conceito. $\mathrm{O}$ resultado, em ambos os casos, afirma a comentadora, é a justificação ideológica do existente, seja porque as condições sociais são entendidas como "naturais", perdendo-se de vista seu devir histórico, ou ainda porque o processo histórico, a partir da ideia de que há um télos a ser alcançado, é considerado essencial, desprezando-se como simples contingência o sofrimento dos indivíduos particulares e a materialidade que compõe a história; seja ainda porque a própria materialidade é ontologizada como essência em si mesma. Conforme sustenta Adorno, só é possível levar adiante a ideia de uma história natural a partir de uma perspectiva crítica, na medida em que se insiste na tensa relação entre estes dois conceitos:
Si es que la cuestión de la relación entre naturaleza e historia se ha de plantear con seriedad, entonces sólo ofrecerá un aspecto responsable cuando consiga captar al Ser histórico como Ser natural en su determinación histórica extrema, en donde es máximamente histórico, o cuando consiga captar la naturaleza como ser histórico donde en apariencia persiste en sí mismo hasta lo más hondo como naturaleza. (Adorno, 1991, p. 117; 2003, p. 604, grifos do autor)

Essa crítica ao estabelecimento de um primado lógico e temporal entre os conceitos de natureza e história está presente de forma mais ou menos explícita no desenvolvimento posterior da obra de Adorno. Embora não seja possível neste trabalho abordar a questão com maior profundidade, importa destacar que os contornos de tal crítica se tornam mais delineados no livro Dialética negativa, em que Adorno radicaliza suas apreciações em relação, por um lado, à filosofia da história de Hegel, especialmente à ideia de uma história universal que confirmaria a marcha triunfal e soberana do Espírito Absoluto e, por outro, à ontologia fundamental de Heidegger, ao seu anseio de tomar o Ser como princípio originário e absoluto. No primeiro caso, trata-se do rechaço ao conceito hegeliano de história como desdobramento racional da verdade e como realização progressiva da liberdade. Para Adorno, a identidade entre o real e o racional presente no sistema hegeliano não é possível não por questões de "insuficiência teórica", mas em decorrência dos limites da realidade e da própria razão: "ninguna Razón legitimadora sabría volver a dar consigo misma en una realidad cuyo orden y 
configuración derrota cualquier pretensión de la Razón" (Adorno, 1991, p. 73; 2003, p. 555). Tal rechaço está ancorado na crítica de Adorno às concepções de história como movimento ascendente em direção a uma unidade sintética, a um "resgate" ou reconciliação de uma totalidade "perdida". Em uma palavra: na crítica às interpretações da história como progresso. Para Adorno, assim como também para Max Horkheimer e, sobretudo, para Walter Benjamin, seus interlocutores mais próximos, a glorificação da história como categoria suprema tem como consequência, em termos filosóficos, a racionalização e a justificação do sofrimento e da violência que seu curso impõe aos indivíduos, em sua particularidade, e à natureza. Se há progresso na história, como elemento articulador e unificador do caráter disperso e caótico dos eventos históricos, o que de alguma forma valida o conceito de "história universal" - que está na base tanto da filosofia hegeliana e das ciências matemáticas de Kant, quanto do desenvolvimento positivista da ciência histórica (Adorno, 2003, p. 3343; 2009, p. 265) -, este só pode ser pensado, em face da vida atormentada e da monstruosidade do existente, num único sentido: como aumento crescente do domínio e da violência contra a natureza humana e inumana. Em um tom muito próximo daquele das teses Sobre o conceito de história de Benjamin (1977, 1985), Adorno afirma que

A história universal precisa ser construída e negada. Depois das catástrofes passadas e em face das catástrofes futuras, a afirmação de um plano do mundo dirigido para o melhor, um plano que se manifesta na história e que a sintetiza, seria cínica. No entanto, não se precisa negar com isso a unidade que solda as fases e os momentos descontínuos, caoticamente estilhaçados, da história, uma unidade que, a partir da dominação da natureza, se transforma em domínio sobre os homens e, por fim, em domínio sobre a natureza interior. Não há nenhuma história universal que conduza do selvagem à humanidade, mas há certamente uma que conduz da atiradeira até a bomba atômica. (Adorno, 2003, p. 3344-3345; 2009, p. 266)

No que diz respeito à crítica a Heidegger (2006), Adorno nutre uma profunda desconfiança em relação ao intento daquele em Sein und Zeit, escrito em 1929, de estabelecer a historicidade como essência ontológica da existência, resolvendo, aparentemente, a disputa entre uma posição histórica e outra ontológica. Para o filósofo frankfurtiano, a tentativa de Heidegger de colocar-se fora da divergência entre história e natureza revela-se, já na origem, um equívoco, uma vez que somente por meio de um conceito de historicidade que se abstrai do sofrimento dos indivíduos particulares e da materialidade, ou seja, por meio de um conceito a-histórico de história, seria possível ontologizar a antítese história-natureza (Adorno, 2003, p. 3407-3408; 2009, p. 297-298). Do mesmo ponto de vista, a filosofia de Heidegger conteria um elemento regressivo - "não se pode sair da história senão por regressão" (Adorno, 2003, p. 2996; 2009, p. 97) ao pressupor o Ser (ou a natureza, que nesse caso constituem sinônimos) como elemento imediato, "como o primun absoluto no processo do mundo" (Duarte, 1993, p. 63). De acordo com Adorno, 
[...] não menos ilusória é já a questão de saber se a natureza se mostra como o elemento absolutamente primeiro, como algo pura e simplesmente imediato em face de suas mediações. Ela representa aquilo que ela persegue sob a forma hierárquica do juízo analítico cujas premissas governam tudo o que segue e repete assim o obnubilamento do qual ela gostaria de escapar. (Adorno, 2003, p. 3407-3408; 2009, p. 297-298)

Não é apenas a relação entre os conceitos de natureza e história que é compreendida como dialética em $A$ ideia de história natural, mas também a própria constituição "interna" de cada uma dessas categorias, uma vez que, ao conterem em seu interior dois níveis antagônicos de significados, tanto natureza quanto história se mostram como conceitos dialéticos em si mesmos. Segundo Buck-Morss (1981, p. 122), cada qual possui um duplo caráter, um aspecto ou significado "positivo" e outro "negativo". Em relação ao conceito de natureza - embora Adorno advirta não ser possível determinar precisamente seu significado por meio de definições prévias, mas somente por mediação na análise -, tem-se, por um lado, como polo "positivo", a sua dimensão materialista, concreta, substrato sobre o qual se desenrola a história da humanidade; ${ }^{2}$

2 Esse polo "positivo" do conceito de natureza também está presente no conceito adorniano de não idêntico, como "algo" irredutível que, apesar da força do princípio de identidade da razão formalizada, subsiste na conceituação da realidade concreta, dos entes particulares; como "[...] lembrança do não conceitual enquanto pressuposição de todos os conceitos, ou enquanto solo alimentício e alvo de qualquer pensamento" (Türcke, aquilo "[...] que sustenta [tragen] a história humana $[\ldots]$, o que nela há de substancial" (Adorno, 1991, p. 104; 2003, p. 589;). ${ }^{3}$ Por outro, o significado "negativo" do conceito de natureza, tal como Adorno o delimita, diz respeito ao mundo natural ainda não transformado pelo trabalho, ainda não incorporado pela história, não conhecido, em uma palavra, não humanizado, e que representa uma ameaça, um fora de controle, ao homem. Trata-se da natureza como mito, o que "[...] está aí desde sempre” (idem, ibidem) e cujo destino será eternamente igual, sem que jamais se possa dele escapar. A eterna remissão de todo ser e acontecer à origem mágica e ancestral, a qual já contém em si a explicação de tudo aquilo que virá - repetição infinita de si próprio -, constitui a característica fundamental do discurso mitológico, e que será posteriormente equiparado ao conceito de natureza,ou, pelo menos, a uma dimensão dele:

As representações míticas também podem se reduzir integralmente a relações naturais. Assim como a constelação de Gêmeos remete, como todos os outros símbolos da dualidade, ao ciclo inescapável da natureza; assim como este mesmo

2004, p. 53). Nas palavras de Adorno (2003, p. 2843-2844; 2009, p. 18): "Em verdade, todos os conceitos,, mesmo os filosóficos, apontam para um elemento não conceitual porque eles são, por sua parte, momentos da realidade que impele à sua formação - primariamente com o propósito de dominação da natureza. [...] A reflexão filosófica assegura-se do não conceitual no conceito".

3 Com o objetivo de manter a fluidez da escrita, pequenas citações diretas das obras de Adorno cujas traduções em espanhol foram consultadas serão vertidas, como neste caso, para o português, mantendo-se a referência à obra da qual o fragmento foi extraído. 
ciclo tem, no símbolo do ovo, do qual provêm os demais, seu símbolo remoto; assim também a balança nas mãos de Zeus, que simboliza a justiça de todo o mundo patriarcal, remete à mera natureza. [...] Os mitos, assim como os ritos mágicos, têm em vista a natureza que se repete. Ela é o âmago do simbólico: um ser ou um processo representado pelo eterno porque deve voltar sempre a ocorrer na efetuação do símbolo. Inexorabilidade, renovação infinita, permanência do significado não são apenas atributos de todos os símbolos, mas seu verdadeiro conteúdo. (Horkheimer; Adorno, 1985, p. 30-31; 2003, p. 1127-1128).

Aliás, não seria exagero dizer que essa forma de compreender a natureza, como conceito que contém dois níveis de significados opostos, é levada ao paroxismo pelos autores da Dialética do esclarecimento, especialmente na abordagem do domínio sobre o ambiente natural por parte do humano - mas também em relação ao domínio de si, daquilo que há de natureza em nós. Quando a natureza se contrapõe ao homem como força mítica, é de advogar o controle e o conhecimento sobre ela por parte da razão e da Aufklärung; porém, quando o controle da natureza adquire a forma de dominação violenta e desmedida, Adorno e Horkheimer mostram que essa mesma razão, convertida em instrumento, se torna mítica:

Os homens sempre tiveram de escolher entre submeter-se à natureza ou submeter a natureza ao eu. Com a difusão da economia mercantil burguesa, o horizonte sombrio do mito é aclarado pelo sol da razão calculadora, sob cujos raios gelados amadurece a sementeira da nova barbárie. Forçado pela dominação, o trabalho humano tendeu sempre a se afastar do mito, voltando a cair sob o seu influxo, levado pela mesma dominação. (Horkheimer; Adorno, 1985, p. 43; 2003, p. 1153)

Modelar no que diz respeito à ambiguidade do conceito de natureza é também a particular interpretação que Adorno e Horkheimer fazem da obra de Homero, a Odisseia, a qual é tomada, no contexto do livro, como um documento filosófico, que representa "um dos mais precoces e representativos testemunhos da civilização burguesa ocidental" (idem, p. 15-16 e p.1101-1102). O herói Ulisses é mostrado em seu percurso de retorno a Ítaca, sua terra natal, como o protótipo do indivíduo burguês (idem, p. 53 e 1177), na medida em que as forças míticas e os perigos que precisou enfrentar para retornar à sua pátria representariam as forças naturais que o humano precisou vencer e dominar para se constituir como sujeito esclarecido. Ulisses vence as divindades que encontra em sua viagem, as quais constituem uma ameaça física e mortal para ele - tal como as forças reais da natureza em relação ao ser humano -, não por ser fisicamente mais forte, mas porque é astuto. Ele só sobrevive à viagem justamente porque se sabe fraco, exercendo o cálculo, o senhorio e a previsibilidade sobre si, sobre seu próprio corpo, sua natureza interna - também fonte de perigos e ameaças para o eu em constituição -, como testemunha o episódio do canto das Sereias. À medida que seu navio se aproxima das ilhas rochosas habitadas por esses seres meio peixe/ave, meio 
mulher, cujo canto mágico é capaz de enfeitiçar os sentidos humanos, levando aquele que o ouve a se atirar no mar atrás dos seus encantos, Ulisses ordena que seus remadores o amarrem ao mastro do navio, de tal modo que possa ouvir o canto sedutor sem que se jogue ao mar e pereça. Ao mesmo tempo, exige que seus comandados, que devem continuar remando, tapem os ouvidos com cera para que não ouçam nem o canto daquelas fadas, nem os suplícios de seu senhor ordenando que o soltem.

Na interpretação de Adorno e Horkheimer, a passagem de Ulisses e seus comandados pela ilha das Sereias representa uma espécie de condensação de todo o percurso de desenvolvimento do esclarecimento: "as medidas tomadas por Ulisses quando seu navio se aproxima das Sereias pressagiam alegoricamente a dialética do esclarecimento" (idem, p. 45 e 1157-1158). Isto porque, conforme interpreta Gagnebin (2003a, p. 51-55), a análise desse episódio permite apreender alguns dos processos nucleares que levam Horkheimer e Adorno a interpretar o esclarecimento como um grande sistema de dominação: dominação não apenas da razão sobre o mito, ou seja, do medo ancestral do homem frágil diante da natureza e da morte pela explicação racional, mas também domínio da natureza externa pelo conhecimento científico e pela técnica e, do mesmo modo, domínio da natureza interna pela repressão e pela educação. Finalmente, ao considerarmos a condição subjugada dos remadores diante de seu senhor Ulisses, o proprietário -, chegamos ao domínio político-econômico: dominação do homem sobre o homem, de uns poucos sobre uma maioria.

O mundo inextrincável e sem saída da natureza mítica, contra o qual Ulisses se coloca, é perigo efetivo e mortal para o herói homérico. Para que Ulisses possa sobreviver e se constituir no oposto rígido da natureza, das divindades que enfrenta, é preciso que se exponha bravamente à morte. Para que possa dominá-la impiedosamente, é preciso, primeiro, que se perca e se abandone à natureza:

As aventuras de que Ulisses sai vitorioso são todas elas perigosas seduções que desviam o eu da trajetória de sua lógica. Ele cede sempre a cada nova sedução, experimenta-a como um aprendiz incorrigível e até mesmo, às vezes, impelido por uma tola curiosidade, assim como um ator experimenta incansavelmente os seus papéis. "Mas onde há o perigo, cresce também o que salva": o saber em que consiste sua identidade e que lhe possibilita sobreviver tira sua substância da experiência de tudo aquilo que é múltiplo, que desvia, que dissolve, e o sobrevivente sábio é ao mesmo tempo aquele que se expõe mais audaciosamente à ameaça da morte, na qual se torna duro e forte para a vida. (Horkheimer; Adorno, 1985, p. 56; 2003, p. 1182)

Entretanto, podemos encontrar também nessa interpretação que Adorno e Horkheimer fazem do périplo de Ulisses um momento "positivo" do conceito de natureza, no sentido expresso anteriormente. Embora os autores não "definam” de forma inequívoca essa dimensão, é possível entrevê-la na qualidade de instância que se contrapõe, como momento de alteridade, como "outro" a ser suprassumido (aufgehoben) superado e conservado ao mesmo 
tempo - no percurso de constituição da subjetividade. Contudo, mesmo nesse caso a natureza não deixa de representar perigo, prazeroso e ameaçador ao mesmo tempo, qual seja: o de retorno a um mítico passado pré-subjetivo, a dissolução do sujeito em uma mera naturalidade primária. Perigo que permanece à espreita a todo o instante, e que não deixa esquecer que a constituição do ego (inclusive em sua forma danificada, o eu petrificado e identificado somente consigo mesmo) resulta, como lembra Habermas (1990), do solapamento daquele vínculo simpático - mas, ao mesmo tempo, homicida - com a natureza: “o medo de perder o eu e o de suprimir com o eu o limite entre si mesmo e a outra vida, o temor da morte e a da destruição, está irmanado a uma promessa de felicidade, que ameaçava a cada instante a civilização" (Horkheimer; Adorno, 1985, p. 44-45; 2003, p. 1155-1156).

Particularmente importante nesse contexto de apreensão da polifonia que tenta ser captada no conceito de natureza em Dialética do esclarecimento, especialmente de seu aspecto "positivo" que acabamos de mencionar, é a interpretação que Adorno e Horkheimer fazem da passagem em que Ulisses e seus remadores encontram os lotófagos. Aqueles que provam do seu alimento, o lótus, sucumbem tal como os que ouvem o canto das Sereias ou aqueles que, se tocados pela vara mágica da semideusa Circe, se transformam em porcos amestrados. No entanto, ao contrário do que acontece no caso do embate com estas e outras entidades mitológicas da narrativa homérica, os que comem o lótus não se encontram sob uma ameaça mortífera: "[...] nenhum mal é feito a suas vítimas", destacam Horkheimer e Adorno (idem, p. 67 e 1203). "A única ameaça é o esquecimento e a destruição da vontade”. O lótus, espécie de narcótico, condena aqueles que provam da sua doçura, como os marinheiros de Ulisses, a um "[...] estado primitivo sem trabalho e sem luta na 'fértil campina" (idem, ibidem), sem vontade alguma de partir desse lugar. Condena, consequentemente, à regressão a uma fase anterior a todo e qualquer tipo de produção (trabalho), a um estado supostamente idílico de reconciliação com a natureza e, portanto, de suposta felicidade e ausência de qualquer carência e sofrimento, a uma protossexualidade. No entanto, advertem Adorno e Horkheimer, "esse idílio é na verdade a mera aparência da felicidade, um estado apático e vegetativo, pobre como a vida dos animais e no melhor dos casos a ausência da consciência da infelicidade" (idem, ibidem).

Antes de seguirmos com a exposição dessa passagem sobre os comedores de lótus, talvez fosse interessante retornar a $A$ ideia de história natural, a fim identificar como Adorno estabelece o duplo caráter do conceito de história, que, segundo nossa interpretação, tem íntima relação com a análise do mencionado episódio da Odisseia. Para Adorno, tal como podemos ler logo nas primeiras páginas do texto-conferência, o aspecto "positivo" do conceito de história reside justamente na capacidade humana de transformação, de transcendência das imposições do ciclo mítico da natureza:

[...] "historia" designa una forma de conducta del ser humano, esa forma de conducta transmitida de unos a otros que se caracteriza ante todo porque en ella aparece lo cualitativamente nuevo, por ser un movimiento que no se desarrolla en 
la pura identidad, en la pura reproducción de lo que siempre estuvo ya allí, sino uno en el verdadero carácter gracias a lo que en él aparece como novedad. (Adorno, 1991, 104105; 2003, p. 590)

Essa promessa de transformação contida na práxis humana não é outra senão aquela feita pela própria Aufklärung: a de desencantamento do mundo, de dissolução dos mitos, da destruição do animismo e de sua substituição pelo conhecimento racional, tal como lemos em Dialética do esclarecimento. Somente a razão seria capaz de guiar com nitidez e segurança a ação humana em direção ao "qualitativamente novo" a que se refere Adorno. Tal promessa também é reafirmada por Ulisses ao renunciar à gratificação imediata de suas pulsões, ao não ceder à tentação - ao contrário dos seus remadores, "menores" e "mais fracos" do ponto de vista da racionalidade - de comer a planta dos lotófagos e de permanecer preso a um mundo idílico sem carências, sem preocupações, angústia ou trabalho, mas, simultaneamente, sem desejos, subjetividade e memória. Somente renegando esse estado de aparente felicidade e de ausência de consciência em relação ao sofrimento é que Ulisses pôde vencer mais esse desafio e avançar em direção à constituição de sua subjetividade e da própria razão. Foi assim que ele conseguiu despertar seus marinheiros que haviam comido o lótus e transportá-los à força, "debulhados em lágrimas, para as naus"; foi como ele e sua tripulação puderam, mesmo com o "coração amargurado" (Horkheimer; Adorno, 1985, p.67; 2003, p. 1205-1206), prosseguir viagem. É o que podemos ler na sequência da análise que Adorno e
Horkheimer fazem desse episódio, anteriormente interrompida:

Mas a felicidade encerra a verdade. Ela é essencialmente um resultado e se desenvolve na superação do sofrimento. É essa a justificação do herói sofredor, que não sofre permanecer entre os lotófagos. Ele defende contra a própria causa deles, a realização da utopia, através do trabalho histórico, pois o simples fato de se demorar na imagem da beatitude é suficiente para roubar-lhes o vigor. Mas ao perceber essa justificação, a racionalidade, Ulisses entra forçosamente no contexto da injustiça. Enquanto imediata, sua própria ação resulta em favor da dominação. Essa felicidade "nos limites do mundo" é tão inadmissível para a razão autoconservadora quanto a felicidade mais perigosa de fases posteriores. (Horkheimer; Adorno, 1985, p. 67; 2003, p. 1204, grifos nossos)

Observa-se, na conferência de 1932, como assinala Buck-Morss (1981, p. 123), que o caráter "negativo" do conceito de história não se deixa entrever, em todas as suas nuanças, no texto em questão. Trata-se da concepção adorniana da história como repetição do sempre-igual, do Immergleichen - tema que é de forte inspiração benjaminiana -, cujos contornos se tornam mais nítidos nas obras escritas em momentos posteriores, especialmente depois das experiências históricas do totalitarismo político e da barbárie racionalizada que assolaram o mundo nas décadas de 1930 e 1940 e que tornaram praticamente impossíveis, inclusive do ponto de vista filosófico, as distinções entre 
os componentes históricos e naturais da catástrofe vivida pela civilização: “o terremoto de Lisboa foi suficiente para curar Voltaire da teodiceia leibniziana, e a catástrofe visualizável da primeira natureza foi insignificante comparada à segunda catástrofe, a catástrofe social que se subtrai à imaginação humana, na medida em que preparou o inferno real a partir do mal do homem" (Adorno, 2003, p. 3416; 2009, p. 299).

\section{0 sempre-igual: a história como catástrofe}

A catástrofe natural-social a que Adorno faz menção no fragmento que encerra a seção anterior é, certamente, Auschwitz e o genocídio administrado, irracionalmente racional, de milhões de pessoas logo antes e durante a Segunda Guerra Mundial na Alemanha nacional-socialista. O próprio título do aforismo da Dialética negativa do qual aquela passagem foi extraída expressa, de forma inequívoca, essa assertiva: Depois de Auschwitz (idem, p. 3415 e 299).

Auschwitz e a experiência dos campos de concentração e de extermínio nazistas ocupam um lugar central no arcabouço teórico de Adorno, o que contribui, de maneira determinante, à elaboração de suas reflexões sobre a arte, a cultura, a ética, a educação e a própria filosofia. A pergunta pelo que é possível, legítimo e necessário fazer depois de Auschwitz lhe é muito presente. Hitler e o nazismo teriam imposto à humanidade um novo imperativo categórico que coloca os destinos da racionalidade sob suspeita, encontrando um momento que já não pode ser justificado por ela, mas apenas pelo esforço da reflexão ética. ${ }^{4}$ Auschwitz

4 Conforme destaca Gagnebin (2003b, p. 105), representa uma inflexão que obriga elevar ao pensamento, à reflexão filosófica mais exigente, a experiência da dor e no impulso de indignação que lhe é correspondente ${ }^{5}$ como momento irredutível da existência que encontra seu desiderato no que é somático (idem, p. 3422 e 302).

Evidentemente, também no que se refere à reflexão histórica, o Schoa (Holocausto) adquire um papel primordial na obra de Adorno: a singularidade inominável de Auschwitz não pode ser interpretada, nos marcos do seu pensamento, como exceção, um "acidente de percurso" na história da humanidade, um "desvio de rota" em relação ao progresso ascendente. Auschwitz é compreendido por Adorno como expressão culminante da racionalidade instrumental, algo não propriamente necessário, mas, por certo, experiência longe de ser qualquer anomalia no processo civilizador e distante de se constituir uma excrescência na marcha triunfal da história.

Se o aspecto "positivo" do conceito de história, tal como Adorno o deli-

Adorno retoma vários elementos da "ética da compaixão" de Schopenhauer, na medida em que a possibilidade de existência de uma ética depois de Auschwitz encontra seu fundamento não em uma norma racional abstrata, mesmo que consensual, como a do imperativo kantiano, "[...] mas sim num impulso pré-racional em direção ao outro sofredor". Sobre o tema consultar o trabalho de Schweppenhäuser (2003).

5 Uma interpretação importante sobre as implicações políticas e éticas da memória dos sobreviventes da barbárie nazista, e sobre a emergência do espaço concentracional como paradigma político do contemporâneo, é a de Agamben (2002), entre outros. Ainda sobre o tema da memória dos sobreviventes de Auschwitz, consultar Seligmann-Silva (2003) 
mita na conferência de 1932, designa a "potência" contida na práxis social dialética, o lado "negativo", por seu turno, está assentado no polo estático da história real, da práxis real humana, como destaca Buck-Morss (1981), que em vez de conduzir da barbárie ao progresso, das forças míticas da natureza ao esclarecimento, reafirma, com força ainda maior, "a reprodução do que sempre já esteve aî" (Adorno, 1991, p. 105; 2003, p. 590), tal como se pode ler na seguinte passagem:

Marx, em sua famosa carta a Kugelmann, preveniu contra a iminente recaída na barbárie, que já então deveria ser visível. Nada poderia expressar melhor a afinidade eletiva entre conservadorismo e revolução. Esta já apareceu aos olhos de Marx como a última "ratio" para evitar o colapso por ele prognosticado. Mas esse medo que, por certo, não foi o menos importante dos motivos de Marx está ultrapassado. A recaída já se produziu. Esperá-la para o futuro, depois de Auschwitz e Hiroshima, faz parte do pobre consolo de que ainda é possível algo pior. [...] Uma práxis oportuna seria unicamente a do esforço de sair da barbárie. [...] Aquilo que, há cinquenta anos, ainda poderia parecer justo por um breve período de tempo, para a esperança demasiadamente abstrata e ilusória de uma transformação total - a violência -, encontra-se, depois do horror nacional-socialista e stalinista, e frente à longevidade da repressão totalitária, inextrincavelmente enredado àquilo mesmo que deveria ter sido mudado. (Adorno, 1995b, p. 214-215; 2003, p. 8682-8683)
Se Adorno não se permite qualquer otimismo em relação ao contemporâneo, tal como "há cinquenta anos", quando ainda fora possível nutrir alguma esperança na transformação do todo, como afirma, não é por "pessimismo" ou pedantismo. São os acontecimentos presentes e a concretização daquela ameaça a qual Marx advertira, a recaída na barbárie, que desautorizam tal sentimento. Conforme aponta Jay (1988, p. 53-54), enquanto Marx viveu numa época marcada pelas tentativas de cumprir as promessas de grandeza contidas nos escritos dos mais diferentes filósofos, especialmente dos metafísicos idealistas alemães, Adorno viveu em momento diferente da história europeia, na qual a filosofia, já bastante castigada e da forma que lhe era possível, buscava entender o monstruoso fracasso daquelas promessas. Destarte, enquanto o primeiro escreveu numa época em que a filosofia "descia", de modo enérgico e agressivo até os recônditos do mundo material, como aliás defendia o próprio Marx na décima primeira tese sobre Feuerbach - plenamente confiante na unidade entre teoria e prática -, as reflexões de Adorno emergem em meio às ruínas que restaram da tentativa de realização da filosofia, tal como lemos na primeira frase da Dialética negativa: "A filosofia, que um dia pareceu ultrapassada, mantém-se viva porque se perdeu o instante de sua realização" (Adorno, 2003, p. 2830; 2009, p. 11).

Adorno não diverge propriamente de Marx no que diz respeito à tarefa da filosofia, a qual, como uma espécie de advogado da razão (Türcke, 2004), deveria auxiliar no seu desdobramento na história e, consequentemente, na realização das promessas contidas em seu próprio conceito. No entanto, Adorno 
discorda profundamente quanto à avaliação dos resultados dessa tarefa, uma vez que se a história é o tribunal no qual a razão é julgada, então o advogado, a filosofia, perdeu a sua causa: "A frase de Marx, de que também a teoria se torna um poder real quando atinge as massas, evidentemente foi invertida pelo percurso do mundo" (Adorno, 1986, p. 70; 2003, p. 5365).

A monstruosidade dos eventos que marcam o século XX como a "era das catástrofes", como o classificou Eric Hobsbawm (2000, p. 112), desnuda o fracasso da filosofia na tarefa de realizar a razão na história. Sua falha é motivo de vergonha, o que significa dizer, como assinala Türcke (2004, p.46), que ela quer desistir de si mesma, abandonar-se, mas não pode. No entanto, é justamente esse sentimento, como expressão, simultaneamente, do autorreconhecimento da culpa e da necessidade de autocrítica, que permite, paradoxalmente, que a filosofia possa continuar com alguma dignidade. Somente pelo reconhecimento da vontade de querer desistir e não conseguir; somente pela desconfiança de sua tradição, de seus métodos, de suas verdades e "sistemas", é que ela pode tornar-se confiável (Türcke, 2004).

É diante desse quadro que se deve compreender o tom sombrio e o gosto amargo das análises de Adorno sobre o tema da filosofia da história presentes em Dialética do esclarecimento, e que já se encontravam, em germe, na conferência de 1932. Acompanhando a argumentação de Buck-Morss (1981, p. 132), pode-se afirmar que o livro escrito com Horkheimer representa menos uma mudança radical de perspectiva e no modo de Adorno compreender a relação entre os conceitos de história e natureza do que o desenvolvimento concreto da ideia de história natural, no sentido da superação da antítese tradicional entre aquelas duas categorias, arrazoada por Adorno na conferência em questão. Em Dialética do esclarecimento, Adorno e Horkheimer evidenciam justamente como momentos da história dinâmica e do mito estático se interpenetram e se justapõem, guardando em suas estruturas elementos um do outro. Não é à toa, então, que o poema épico de Homero, a Odisseia, e seu herói Ulisses sejam tomados como alegoria do processo de constituição do homem no sentido moderno, ou seja, racional e esclarecido. Também é nesse contexto que os fenômenos sociais mais prementes da época analisados pelos autores: a ciência, o progresso técnico, o antissemitismo e a indústria cultural, são interpretados como manifestações da violência arcaica contra a natureza. De forma semelhante ao modo como Adorno operara com os conceitos de natureza e história em $A$ ideia de história natural, uma série de outros conceitos antitéticos (magia-ciência, esclarecimento-mito, progresso-regressão etc.) são empregados como ferramentas cognitivas para desmistificar tanto a relação entre eles, quanto a realidade que buscam definir (Buck-Morss, 1981, p. 132).

No entanto, há uma diferença fundamental entre esses dois momentos da obra de Adorno. Se as condições históricas em 1932 ainda permitiam a existência de algum potencial objetivo para a revolução diante da ordem burguesa em ruínas - e, consequentemente, uma discreta esperança do ponto de vista teórico -, aquelas do período que culmina na redação da Dialética do esclarecimento, o primeiro terço dos anos de 1940, eram completamente diferen- 
tes. Se no primeiro caso, como destaca Buck-Morss (1981, p. 134), o principal obstáculo cognitivo para a realização da revolução, conforme preconizava Lukács (2001), parecia ser a reificação (Verdinglichung), a corresponder ao fetichismo da realidade, transformando-a em uma espécie de "segunda natureza" e ocultando sua dimensão histórica, no segundo "no era ya la estática apariencia de la realidad la que requería ser desmitificada, sino la apariencia del progreso histórico" (Buck-Morss, 1981, p. 134). Entretanto, mesmo nesse caso, Adorno procura fidelidade a um princípio já manifesto em 1932, o qual apreendera do relacionamento intelectual (e do embate!?) com Walter Benjamin: de que o presente constitui o elemento de mediação do conhecimento histórico e da relação com o passado, inclusive, para a crítica do próprio presente (Benjamin, 1977, p. 251-261; 1985, p. 222-232). É desse contexto que emerge uma das críticas mais vorazes à filosofia da história de Hegel que Adorno faz na Minima Moralia:

Se a filosofia de Hegel tivesse incluído nossa época, as bombas-robô de Hitler teriam encontrado nela um lugar [...] entre os fatos empíricos selecionados nos quais se exprime imediata e simbolicamente o estado atingido pelo espírito do nosso mundo. Como o próprio fascismo, os robôs são lançados ao mesmo tempo e desprovidos de subjetividade. Como ele, aliam a mais avançada perfeição técnica à cegueira total. Como ele, despertam um terror mortífero e são inteiramente vãos. - "Eu vi o espírito do mundo", não a cavalo, mas sobre asas e sem cabeça, e isso é ao mesmo tempo uma refutação da filosofia da histó- ria de Hegel. (Adorno, 1993, p. 47; 2003, p. 1737-1738).

A presença de Walter Benjamin nos escritos de Adorno é muito marcante e os leitores familiarizados com a obra do filósofo berlinense percebem claramente a influência de suas ideias também no que se refere à temática da filosofia da história. E isso não apenas no que diz respeito à concepção de história natural desenvolvida na conferência pronunciada na Universidade de Frankfurt, onde Benjamin é referência direta e explícita, mas também no que diz respeito ao polo estático e "negativo" do conceito de história, desenvolvido, sobretudo, a partir do livro escrito com Horkheimer, e que constitui, como mencionado, elemento central nos trabalhos posteriores de Adorno. Se em A ideia de história natural a referência fundamental é o estudo sobre o Trauspiel (Benjamin, 1984), em Dialética do esclarecimento a influência decisiva, embora de forma menos explícita - mas não menos perceptível -, vem das teses Sobre o conceito de história (Benjamin, 1977, 1985), último trabalho escrito por Benjamin antes de seu suicídio em 1940.

Nesse texto, como assevera Löwy (2002, p. 205), Benjamin combate a ideologia do progresso em suas várias frentes e componentes: o evolucionismo darwinista e o crescente domínio técnico da natureza; o determinismo de caráter científico-natural; a convicção cega na superação das contradições sociais do capitalismo e o consequente otimismo político, expresso no dogma da vitória "inevitável” do comunismo; a ideologia social-democrata alemã que acreditava que o desenvolvimento técnico era o declive da "corrente" a favor da qual a classe operária supunha "nadar" (Benjamin, 1977, p. 256; 1985, p. 227). 
Dessas análises de Benjamin, que tanto influenciaram Adorno, a que deixou uma impressão mais profunda e duradoura é provavelmente a tese IX, que se apresenta como comentário de um quadro do pintor alemão Paul Klee, intitulado Angelus Novus. A partir da correspondência - no sentido baudelairiano do termo ${ }^{6}$ - entre elementos sagrados e profanos, políticos e teológicos (Löwy, 2005), característicos não apenas no texto em questão, mas na obra de Benjamin como um todo, o anjo retratado por Klee teria a aparência semelhante àquela do "anjo da história": "[...] representa [o quadro] um anjo que parece quer afastar-se de algo que ele encara fixamente. Seus olhos estão escancarados, sua boca dilatada, suas asas abertas. O anjo da história deve ter esse aspecto. Seu rosto está dirigido para o passado. Onde nós vemos uma cadeia de acontecimentos, ele vê uma catástrofe única $[\ldots]$ (Benjamin, 1977, p. 255; 1985, p. 226).

O anjo da história gostaria de parar e cuidar das feridas das vítimas caídas entre os escombros - ruínas da história, de uma sucessão interminável de catástrofes - que se amontoam sob seus pés, diz Benjamin. Mas suas asas estão abertas e ele não consegue fechá-las, pois uma tempestade, "que sopra do paraíso", o impulsiona inexoravelmente para o futuro, que nada mais é do que a repetição do passado, do sempre-igual (Immergleichen), do qual se falou antes, de novas e mais destruidoras hecatombes (Löwy, 2005, p. 90). O correspondente profano da imagem teológica de uma tempestade que nos distancia

Sobre o emprego que Benjamin faz do conceito de correspondência, o qual ele toma emprestado da poesia lírica de Baudelaire, consultar Gagnebin (2004, especialmente p. 31-54). cada vez mais do Jardim do Éden é, de acordo com Benjamin, o progresso, que nos conduz para o oposto do paraíso, ou seja, o inferno, cuja quintessência, segundo Löwy (idem, ibidem), é a eterna repetição do mesmo, do sempre-igual (Immergleichen). É nesses termos que Adorno e Horkheimer retomam essa passagem, quase literalmente, no último capítulo da Dialética do esclarecimento: "O anjo com a espada de fogo, que expulsou os homens do paraíso e os colocou no caminho do progresso técnico, é o próprio símbolo desse progresso" (Horkheimer; Adorno, 1985, p. 169; 2003, p. 1425-1426).

\section{Sobre o conceito de segunda natureza}

A hipótese de que as catástrofes históricas e sociais, como fora Auschwitz, possuem uma estrutura e caráter eletivamente semelhantes à dos fenômenos naturais de proporções destrutivas, como ciclones, terremotos, tempestades, maremotos, entre outros, remete a um elemento central da concepção de domínio da natureza em Adorno, que é o conceito de segunda natureza (zweite Natur). Tal categoria já está presente em $A$ ideia de história natural, na mudança de perspectiva que Adorno propõe ao tratar dialeticamente os conceitos de natureza e história, e constitui, como assevera Adorno (1991, p. 118; 2003, p. 605), a fonte da qual brota sua concepção de história natural.

Diferentemente do polo "positivo" do conceito de natureza mencionado anteriormente, e que representa para Adorno uma "primeira natureza" no sentido de um mundo sensível, de uma natureza concreta, particular, tanto humana quanto inumana, e que é violentada como mera contingência pelo curso 
de uma história linear e ascendente, o conceito de "segunda natureza" constitui uma ferramenta crítica por meio da qual o autor procura desmascarar a aparência mítica de uma realidade que aparece como absoluta e a-histórica (Buck-Morss, 1981, p. 124).

A origem desse conceito, destaca Adorno na segunda parte do texto-conferência, remete a uma tradição histórico-filosófica da estética, os livros $A$ teoria do romance (Lukács, 2000) e A origem do drama barroco alemão (Benjamin, 1984). Lukács utilizara o conceito de "segunda natureza" para descrever aquilo que denominava mundo da convenção, um mundo vazio de sentido que, embora fosse criado pelo homem, era composto de coisas estranhas a ele, que se lhe apresentavam como cifras que não conseguia compreender. Nas palavras de Adorno, a base de tal conceito em Lukács seria a seguinte:

[...] en el terreno historicofilosófico, una de las ideas generales de Lukács es la de mundo pleno de sentido y mundo vacío de sentido (mundo inmediato y enajenado [entfremdete], de la mercancía), y trata de representar ese mundo enajenado. A ese mundo, como mundo de las cosas creadas por los hombres y perdidas para ellos, lo llama mundo de la convención. (Adorno, 1991, p. 118-119; 2003, p. 605-606) ${ }^{7}$

Na passagem a que Adorno se refere, Lukács (2000, p. 62) não define "mundo alienado" como "mundo das mercadorias". A delimitação do conceito de segunda natureza como mundo das mercadorias só foi formulada posteriormente em História e consciência de classe, de 1923 (Lukács, 2001). Segundo Buck-Morss (1981), Adorno, que certamente conhecia essa referência, preferiu ocultar essa informação em razão da preferência de seus interlocutores pela obra de Lukács anterior à influência marxista.
Assim como os fetiches arcaicos, o mundo das convenções exerce um poder mítico sobre a realidade, ocultando-lhe suas origens históricas e fazendo-a se impor sobre os homens como um destino implacável (Lukács, 2000, p. 65). Destituir o mítico poder do "mundo da convenção", revelando a dimensão histórica de sua constituição, representa o ponto de partida da discussão sobre o entrelaçamento entre história e natureza:

Ese hecho, el mundo de la convención tal como es producido históricamente, el de las cosas que se nos han vuelto ajenas, que no podemos descifrar pero con las que nos tropezamos como cifras, es el punto de partida de la problemática que hoy presento aquí. Visto desde la filosofía de la historia, el problema de la historia natural se plantea para empezar como la pregunta de cómo es posible aclarar, conocer ese mundo enajenado, cosificado [dinghafte], muerto. (Adorno, 1991, p. 120; 2003, p. 606-607)

Embora o deciframento do mundo da convenção constitua o ponto de partida das reflexões de Adorno, e "Lukács já tinha visto este problema no que ele tem de estranho e de enigma" (idem, p. 120 e 607), havia ainda "[...] o outro lado do fenômeno", o qual, segundo o frankfurtiano, Lukács não alcançou. O que Adorno critica em $A$ teoria do romance é justamente o fato de o seu autor conceber somente em termos metafísicos a transcendência do mundo da convenção, do mundo alienado, "[...] sob a categoria da ressurreição [Wiedererweckung] teológica, sob o horizonte escatológico" (idem, p. 121 e 608). A suspeita de Adorno 
que recai sobre todas as filosofias positivas da história, especialmente aquelas que, como a lukacsiana, atribuem à história - em oposição à natureza - o território privilegiado de realização da liberdade, está assentada no rechaço da crença da história como progresso, como uma "realidade superior" na qual uma lei intrínseca - ou um agente histórico, como o proletariado no caso de Lukács garantiria a identidade entre razão e realidade. Para Adorno, na verdade, a conversão da história em princípio ontológico fundamental não é propriamente oposta à posição da natureza como fundamento absoluto e simples imediatez, mas idêntica a ela naquilo que possui de mais violento: o inescapável ciclo mítico, ao qual vimos Adorno se referir algumas páginas antes, quando esboçamos sua compreensão do conceito de natureza no texto-conferência de 1932. Semelhante interpretação pode ser depreendida também da crítica que Adorno dirige à metafísica hegeliana, que andaria de mãos dadas com o feitiço mítico:

O seu [de Hegel] espírito do mundo é a ideologia da história natural. Para ele, a história natural chama-se espírito do mundo por força de sua violência. O domínio torna-se absoluto, ele se projeta sobre o ser mesmo que se mostra aí como espírito. A história, porém, a explicação de algo que ela já deve ter sido desde sempre, adquire a qualidade do a-histórico. Em meio à história, Hegel toma o partido daquilo que ela possui de imutável [Immergleichheit], da perpetuação do igual, da identidade do processo para o qual a totalidade seria salva. É preciso acusá-lo sem qualquer metáfora de uma mitologia da história. (Adorno, 2003, p. 3404; 2009, p. 295-296)
O maior perigo de tais filosofias da história, na medida em que se convertem em teodiceias, reside, segundo Adorno, na justificação do sofrimento da existência humana individual, mas também da natureza como um todo, em nome de uma "lei" mais elevada, tal como podemos ler na seguinte passagem, extraída do aforismo "Para uma crítica da filosofia da história", presente nas "Notas e esboços" de Dialética do esclarecimento:

Na filosofia da história repete-se o que aconteceu no cristianismo: o bem, que na verdade permanece entregue ao sofrimento, é disfarçado como uma força determinando o curso da história e triunfando no final. Ele é divinizado como espírito do mundo ou, pelo menos, como uma lei imanente. [...] Visto que a história enquanto correlato de uma teoria unitária, como algo de construível, não é o bem, mas justamente o horror, o pensamento, na verdade, é um elemento negativo. A esperança de uma melhoria das condições, na medida em que não é uma mera ilusão, funda-se menos na asseveração de que elas seriam as condições garantidas, estáveis e definitivas, do que precisamente na falta de respeito por tudo aquilo que está tão solidamente fundado no sofrimento geral. (Horkheimer; Adorno, 1985, p. 209; 2003, p. 1509-1510)

É nesse contexto que Adorno recorre ao supramencionado livro de Benjamin (1984), especialmente à categoria de transitoriedade (Vergänglichkeit), como antídoto à forma escatológica como Lukács compreendeu a relação entre história e natureza. Para 
Adorno, assim como para Benjamin, é no caráter daquilo que é passageiro transitório, portanto - que se estabelece o ponto de convergência mais profundo entre história e natureza, pois aquilo que é histórico, conforme destaca Chiarello (2006, p. 144-145), "se converte em natureza morta, dado seu caráter efêmero, assim como, em contrapartida, o que é natureza, revelando-se passageira, apresenta-se então como história." E aqui residiria, segundo Adorno, o ponto de diferenciação entre Lukács e Benjamin: "Si Lukács hace que lo histórico, en cuanto sido, se vuelva a transformar en naturaleza, aquí se da [com Benjamin] la otra cara del fenómeno: la misma naturaleza se presenta como naturaleza transitoria, como historia" (Adorno, 1991, p. 123; 2003, p. 609).

Partindo da interpretação benjaminiana de $A$ origem do drama barroco alemão (Benjamin, 1984), que consistia em tomar todo ente como escombro e fragmento, como algo no qual estão "entalhados" natureza e história, Adorno enfatizará a alegoria da caveira ou a imagem do calvário (Vorstellung der Schädelstätte) como momentos expressivos do conceito que cognomina de história natural:

Esa relación alegórica contiene en sí el barrunto [Ahnung - pressentimento, sinal] de un procedimiento que pudiera lograr interpretar la historia concreta con sus propios rasgos como naturaleza, y hacer a la naturaleza dialéctica bajo figura de historia. El desarrollo de esta concepción es, una vez más, la idea de historia natural. [...] en el pensamiento radicalmente histórico-natural, todo ente se transfor- ma en escombro y fragmento, en un calvario en el que hay que encontrar la significación, en el que se ensamblan naturaleza e historia y la filosofía de la historia se hace con la tarea de su interpretación intencional. (idem, p. 126-127 e 613-614)

No entanto, é importante advertir que Adorno não substitui a interpretação lukacsiana de segunda natureza, como mundo da convenção, como "natureza petrificada", morta, pela de Benjamin, que mostra a natureza como transitória, como história. A partir de ambos os significados, Adorno compõe uma complexa constelação conceitual: a natureza é, em seu caráter efêmero, histórica; o histórico é natureza que se esfumaça. Por isso, a segunda natureza decifra-se como transitória, um significado que se abre ao descontínuo, que desencanta o mítico (Adorno, 1985, p. 128; 2003, p. 616; Aguilera, 1991, p.36). Um exemplo, dado pelo próprio Adorno, pode nos ser bastante útil na tentativa de apreender o que ele quer dizer quando afirma que o novo, aquilo que é radicalmente histórico, se apresenta, na verdade, como arcaico, como mito. Vejamos:

La historia es "más mítica allí donde más histórica es". Aquí radican las mayores dificultades. En lugar de desarrollar ideas en términos generales, daré un ejemplo: el de la apariencia [Schein]; y ciertamente me refiero a la apariencia en el sentido de esa segunda naturaleza de la que se hablaba. Esa segundo naturaleza, en tanto se ofrece plena de sentido, es una naturaleza de apariencia, y en ella la apariencia 
está producida históricamente. Es aparente, porque la realidad se nos ha perdido y creemos entenderla plena de sentido siendo así que está vacía, o porque introducimos en ella intenciones subjetivas a modo de significados suyos, como en la alegoría. Ahora bien, lo más notable sin embargo es que esa entidad intrahistórica, "la apariencia", es la misma del género mítico. (Adorno, 1991, p. 132; 2003, p. 619-620)

É nesse registro que Buck-Morss (1981, p. 125) dirá que a categoria de segunda natureza forma nos escritos de Adorno uma constelação de conceitos críticos ao lado de "fetiche", "reificação", "destino", "encantamento" e "mito", os quais lhe permitem, ao examinar os fenômenos culturais e sociais em sua forma "dada", "aparente", penetrar nas ocas convenções e destituí-las da exterioridade "natural" da qual se revestem, desvelando, assim, a historicidade de suas produções. $\mathrm{O}$ conceito de segunda natureza, como ferramenta conceitual empregada na desmistificação da realidade, constitui peça-chave na ideia de uma história natural, na relação de oposição dialética entre história e natureza: toda vez que os fenômenos sociais aparecem como "naturais", Adorno os expõe como "segunda natureza", ou seja, como produzidos histórica e socialmente. Em contrapartida, aquilo que aparece como um processo puramente "histórico" é revelado em termos de "primeira natureza", de natureza material, concreta e transitória, que subsiste no interior, nas entranhas deste processo.

$\mathrm{Na}$ verdade, esta intencional ambivalência, este procedimento de conectar um conceito ao seu outro dialético, como no caso de natureza e história, numa espécie de "curto circuito conceitual", constitui uma das premissas fundamentais do pensamento de Adorno. Conceitos antitéticos como esclarecimento e mito, sujeito e objeto, particular e universal, indivíduo e sociedade, progresso e regressão, identidade e não identidade são utilizados dessa forma por Adorno ao longo de toda a sua obra, e encontram em Dialética negativa (Adorno, 2003, 2009) seu fundamento filosófico. Ao insistir na contradição, na tensão dialética nunca dissolvida no momento de síntese, em uma palavra, numa dialética sem identidade (Tiburi, 1995, p. 75), Adorno leva até as últimas consequências a necessidade do pensamento - e da filosofia, portanto - , de expressar de forma adequada seu objeto: se a objetividade é contraditória em si mesma, em sua própria facticidade, em suas relações na história e entre seus elementos internos (idem, ibidem), então essas contradições deveriam refletir-se também no âmbito da teoria. "Ela [a consciência] não pode eliminar de si mesma a contradição objetiva e suas emanações por meio de arranjo conceitual", afirma Adorno (2003, p.30693070; 2009, p. 133). Na medida em que a realidade social não se modifica e que o antagonismo e as contradições permanecem inalteradas no âmbito das estruturas sociais, então elas não podem ser resolvidas ou reconciliadas no plano da reflexão. Conforme sintetiza Buck-Morss (1981, p. 130), "'aceptada la premisa de una realidad contradictoria, esencialmente antagónica, está clara la razón que llevó a Adorno entender que el conocimiento del presente requería la yuxtaposición de conceptos contradictorios cuya tensión mutuamente negadora no podía disolverse". 
Uma nota: segunda natureza, técnica e educação

O impulso que move as reflexões de Adorno sobre o tema do domínio da natureza na filosofia da história constitui também elemento-chave para compreensão do tema da educação em sua obra, e isso não apenas nos escritos do autor mais diretamente vinculados à problemática pedagógica, como os reunidos em Erziehung zur Mündigkeit. Isto porque o imperativo de que Auschwitz, enquanto catástrofe natural-social, não se repita (Adorno, 2003, p. 3422; 2009, p. 302) representa uma das assertivas mais importantes no que diz respeito às reflexões de Adorno sobre o contemporâneo e, em seu interior, a educação.

De fato, em Dialética negativa (Adorno, 2009, p. 302-303), em formulação bastante semelhante àquela conhecida de Educação após Auschwitz, lemos que

Em seu estado de não liberdade, Hitler impôs aos homens um novo imperativo categórico: instaurai o vosso pensamento e a vossa ação de tal modo que Auschwitz não se repita, de tal modo que nada desse gênero aconteça. Esse imperativo é tão refratário à sua fundamentação quanto outrora o dado do imperativo kantiano. Tratá-lo discursivamente seria um sacrilégio: é possível sentir nele corporalmente o momento de seu surgimento junto à moralidade. Corporalmente porque ele é o horror que surgiu praticamente ante a dor física insuportável à qual os indivíduos são expostos mesmo depois que a individualidade, enquanto forma de reflexão espiritual, se prepara para desaparecer.
Contribuir na desbarbarização da sociedade, afastando as condições que geram aquilo que, em termos históricos, culminou em Auschwitz, seria a tarefa de toda a educação política, algo que deveria, segundo afirma, prescindir de qualquer tipo de justificação (Adorno, 1995a, p. 119; 2003, p. 8516). Para Adorno, não se trata da ameaça de uma regressão à barbárie, pois Auschwitzfoi a própria regressão. Embora seja verdade que para o filósofo frankfurtiano Auschwitz não se repetirá, uma vez que se trata da experiência do inominável, do momento único e irreproduzível, continuaremos vivendo sob o signo da barbárie enquanto persistirem, no que têm de fundamental, as condições que tornaram possível essa regressão. Que esse impulso possa ser atualizado a todo momento, é preciso evitar, seja na forma das grandes catástrofes que nos rondam, ou ainda - e hoje talvez principalmente - nas expressões reificadoras que naturalizam a barbárie e procuram legitimar administrativamente as formas de dominação. É nesse sentido, como expressão culminante de um processo que nos compõe, que, conforme destaca Duarte (1993, p. 99), Adorno afirmará em Minima Moralia que Auschwitz não representa o desastre na sua totalidade, mas apenas o clímax de uma catástrofe permanente, a qual seria perceptível em diversas manifestações daquilo que ele denominou mundo administrado: "Milhões de judeus foram assassinados, e isso deve ser um mero entreato [Zwischenspiel] e não a própria catástrofe" (Adorno, 1993, p. 47; 2003, p. 1738).

Expressão de uma dialética do esclarecimento, Auschwitz apresenta-se vinculado a uma estrutura psíquica e social reificada, expressão da frieza da 
subjetividade burguesa. Como bem demonstram Adorno e Horkheimer nas análises que fazem do antissemitismo, presentes no terceiro capítulo de Dialética do esclarecimento, a feliz apatia sádica, expressa de maneira emblemática no nacional-socialismo - mas não apenas nele - vincula-se à autoconservação de um ego que, quando ameaçado, procura ser mais idêntico do que si mesmo e, portanto, não diferente dos outros, mas, sim, indiferente - ou, o que faz parte do mesmo impulso, portador do desejo de destruição do outro.

Nessa tarefa pedagógica irrenunciável coloca-se a problemática de uma história natural, processo de ocultamento do movimento dialético de dominação da natureza, que reinscreve o círculo infernal do sempre-igual. Essa hipostasia, que é expressão de um esquecimento da natureza no sujeito (Adorno, 2009), pontifica, entre outros, na equação entre corpo, técnica e produção da consciência reificada (verdinglichter Bewußtsein), como se sugere em Educação após Auschwitz (Adorno, 1995a).

Nesse quadro é que Adorno (1995a), retomando questões que se originam de seu texto-conferência, e que ganham sua extensão mais ampla em Dialética negativa, inscreve um importante comentário sobre a educação do corpo, destacando que, em cada situação na qual a consciência é mutilada (verstümmelt), as consequências se refletem sobre o corpo e a esfera corporal de uma maneira não livre e propícia à violência e à crueldade (Adorno, 1995a, p. 126-127; 2003, p. 8527-8528). Esse comentário, como se observa, aparece relacionado ao problema da consciência reificada e da frieza burguesa, expressões de seres humanos cuja energia libidinal foi, nos marcos da personalidade autoritária e do caráter manipulador, desviada para a fúria organizativa, para o apego às máquinas, aos instrumentos, para o culto a uma eficiência que, ao celebrar os meios - e dentre eles a técnica-, desconheceu e desconhece os fins. Em uma palavra, trata-se de pessoas que, encobertas pelo véu tecnológico (technologischer Schleier), seriam incapazes de amar, de estabelecer vínculos profundos, experiências humanas diretas com outras pessoas. Estabelece-se, então, com grande visibilidade na relação com o próprio corpo, uma segunda natureza como catástrofe.

O domínio e a manipulação instrumental da natureza, para a qual a técnica é fator indispensável, acabaria levando inexoravelmente à instrumentalização do humano, assim como à conversão daquela em matéria bruta, em puro objeto, conduziria não apenas à reificação das relações sociais, mas também à conversão da naturalidade primária do humano, seu corpo, em algo de morto. Ao considerarmos a relação entre corpo e reificação nos marcos do conceito de domínio da natureza no pensamento de Adorno, a técnica pode ser interpretada como uma espécie de segunda natureza como catástrofe, que engendraria um profundo processo de esquecimento do passado, da nossa relação de compartilhamento com a natureza, ao mesmo tempo em que sua força proviria justamente desse esquecimento. A técnica seria, então, uma forma racional de organizar e potencializar uma relação de severidade e de domínio absoluto sobre o próprio corpo. O refinamento trazido pelo aparato tecnológico e a instrumentalidade corporal acabariam convertendo-se em mediadores da perversa equação entre celebração e desprezo, de amor-ódio pelo 
corpo (Horkheimer; Adorno, 1985, p. 217; 2003, p. 1526).

$\mathrm{O}$ véu agitado da intemporalidade técnica, "simbolizada conforme o modelo de uma roda girando monotonamente", escamoteia a irracionalidade e promove uma aparente identidade entre a organização social e os seus habitantes, dissimulando uma visão de mundo que deve, a todo custo, evitar modificar-se para não lembrar da própria irracionalidade e com isso ruir (Adorno, 2001, p. 122; 2003, p. 7587 7588). Afinal, diz Adorno em Dialética negativa, "universais são o pressentimento e o temor de que a dominação da natureza contribua por meio do progresso para tecer cada vez mais a desgraça da qual ela queria se proteger: rumo àquela segunda natureza para a qual a sociedade se expandiu" (Adorno, 2003, p. 2932; 2009, p. 65).

\section{Referências bibliográficas}

ADORNO, Theodor W. Actualidad de la Filosofía. Barcelona: Paidós, 1991.

. Dialética negativa. Rio de Janeiro: Jorge Zahar, 2009.

Educação e emancipação. Rio de Janeiro: Paz e Terra, 1995a.

Gesammelte Schriften. Frankfurt am Main: Suhrkamp, 1986/ Berlin: Directmedia, 2003 (Digitale Bibliothek Band 97).

Minima Moralia: reflexões a partir da vida danificada. 2. ed. São Paulo: Ática, 1993.

Palavras e sinais: modelos críticos

2. Petrópolis: Vozes, 1995b.

Prismas: crítica cultural e sociedade. São Paulo: Ática, 2001.

Sociedade industrial ou capitalismo tardio? In: COHN, Gabriel (Org.).
Coleção Grandes Cientistas Sociais: Adorno. 2. ed. São Paulo: Ática, 1986. p. 62-75.

AGAMBEN, Giogio. Homo Sacer: o poder soberano e a vida nua. Belo Horizonte: EDUFMG, 2002.

Aguilera, Antonio. Introducción: lógica de la descomposición. In: ADORNO, Theodor W. Actualidad de la Filosofía. Barcelona: Paidós, 1991.

BENJAMIN, Walter. Iluminationen: Ausgwählte Schriften I. Frankfurt: Suhrkamp, 1977.

Obras escolhidas I: magia e técnica, arte e política. 4. ed. São Paulo: Brasiliense, 1985.

Origem do drama barroco alemão. São Paulo: Brasiliense, 1984.

BUCK-MORSS, Susan. Origen de la Dialéctica Negativa: Theodor W. Adorno, Walter Benjamin y el Instituto de Frankfurt. Cerro del Agua: Siglo XXI Editores, 1981.

CHIARELLO, Maurício. Natureza-morta: finitude e negatividade em T. W. Adorno. São Paulo: EDUSP, 2006.

DUARTE, Rodrigo. Mímesis e racionalidade. São Paulo: Loyola, 1993.

GAGNEBIN, Jeanne Marie. Após Auschwitz. In: SELIGMANN-SILVA, Márcio (Org.). História, memória, literatura: o testemunho na era das catástrofes. Campinas: Editora da UNICAMP, 2003b. p. 91-112.

História e narração em Walter Benjamin. São Paulo: Perspectiva, 2004.

Lembrar escrever esquecer. São Paulo:

Editora 34, 2006.

.O que significa elaborar o passado? In: PUGCI, Bruno; LASTÓRIA, Luiz Antonio Calmon Nabuco; COSTA, Belarmino César Guimarães da. Tecnologia, cultura e formação: ainda Auschwitz. São Paulo: Cortez, 2003c. p. 35-44.

. Resistir às Sereias. CULT - Revista Brasileira de Cultura, São Paulo, n. 72, p. 5359, 2003a. 
HABERMAS, Jürgen. Pré-história da subjetividade ou autoafirmação selvagem. In: FREITAG, Bárbara; ROUANET, Sérgio Paulo (Orgs.). Coleção Grandes Cientistas Sociais: Habermas. São Paulo: Ática, 1990. p. 139-150.

HEIDEGGER, Martin. Ser e tempo. Petrópolis: Vozes, 2006.

HOBSBAWM, Eric. Era dos extremos: o breve século XX - 1914-1991. 2. ed. São Paulo: Companhia das Letras, 2000.

HORKHEIMER, Max; ADORNO, Theodor W. Dialektik der Aufklärung: Philosophische Fragmente. In: ADORNO, Theodor W. Gesammelte Schriften. Frankfurt am Main: Suhrkamp, 1986/ Berlin: Directmedia, 2003. p. 1087-1643 (Digitale Bibliothek Band 97).

Dialética do Esclarecimento: fragmentos filosóficos. Rio de Janeiro: Zahar, 1985.

JAY, Martin. As ideias de Adorno. Tradução de Adail U. Sobral. São Paulo: Cultrix; EDUSP, 1988.

LÖWY, Michael. A filosofia da história de Walter Benjamin. Estudos Avançados, São Paulo, v. 16, n. 45, p. 199-206, ago. 2002.

Walter Benjamin: aviso de incêndio.

Uma leitura das teses "sobre o conceito de história”. São Paulo: Boitempo, 2005.

LUKÁCS, Georg. História e consciência de classe. São Paulo: Martins Fontes, 2001.

A teoria do romance. São Paulo: Duas Cidades; Editora 34, 2000.

SELIGMANN-SILVA, Márcio (Org.). História, memória, literatura: o testemunho na era das catástrofes. Campinas: Editora da UNICAMP, 2003.

SCHWEPPENHÄUSER, Gerhard. Filosofia moral negativa de Theodor W. Adorno. Educação \&̊ Sociedade, Campinas, v. 24, n. 83, p. 391-415, ago. 2003.

TIBURI, Márcia. Crítica da razão e mímesis no pensamento de Theodor W. Adorno. Porto Alegre: EDIPUCRS, 1995.
TÜRCKE, Christoph. Pronto-socorro para Adorno: fragmentos introdutórios à dialética negativa. In: ZUIN, Antônio Álvaro Soares; PUCAI, Bruno; RAMOS-DE-OLIVEIRA, Newton. (Orgs.). Ensaios frankfurtianos. São Paulo: Cortez, 2004. p. 61-74.

JAISON JOSÉ BASSANI é professor do Departamento de Educação Física e dos Programas de Pós-Graduação em Educação e Educação Física da Universidade Federal de Santa Catarina (UFSG). Doutor em educação pela UFSC. Membro do Núcleo de Estudos e Pesquisa Educação e Sociedade Contemporânea (UFSG/ CNPq). Publicou recentemente, em coautoria com Alexandre F. Vaz, Técnica, corpo e coisificação: notas de trabalho sobre o tema da técnica em Theodor W. Adorno (Educação E Sociedade, v. 29, p. 99-118, 2008), além de outros trabalhos sobre Adorno e sobre a educação do corpo no contemporâneo. Pesquisa em andamento, apoiada financeiramente pelo CNPq (Processo n. 400681/20099, Edital MCT/CNPq 02/2009): Corpo e rememoração da natureza no sujeito: uma investigação na dimensão pedagógica da filosofia de Theodor W. Adorno. E-mail: jaisonbassani@uol.com.br

ALEXANDRE FERNANDEZ VAZ, doutor pela Leibniz Universität, Hannover, Alemanha, é professor dos Programas de Pós-Graduação em Educação e Interdisciplinar em Giências Humanas, da UFSC; coordenador do Núcleo de Estudos e Pesquisas Educação e Sociedade Contemporânea (UFSC/CNPq). Pesquisador CNPq - Fundamentos da Educação. Entre livros, capítulos de li- 
vro e artigos em periódicos publicados, destacam-se Sport und Sportkritik im Kulturund Zivilisationsprozess: Analysen nach Horkheimer und Adorno, Elias und DaMatta (Frankfurt am Main: Afra, 2004) e $A$ indústria cultural hoje (organizado com Fabio Akcelrud Durão e Antonio Álvaro Soares Zuin, São Paulo: Boitempo, 2008). Atualmente dirige dois projetos de pesquisa, ambos apoiados pelo CNPq: Teoria Crítica, Racionalidades e Educação II (Auxílios pesquisa, bolsas de produtividade em pesquisa, doutorado, mestrado, iniciação científica, iniciação científica júnior e apoio técnico à pesquisa) e Documentação, sistematização e interpretação de boas práticas pedagógicas nos processos de educação do corpo na escola (Auxílio-pesquisa - Edital Pro-sul). E-mail:alexfvaz@uol.com.br

Observação: O trabalho apresenta resultados parciais dos projetos Corpo e rememoração da natureza no sujeito: uma investigação na dimensão pedagógica da filosofia de Theodor W. Adorno, financiado pelo CNPq (Processo n. 400681/2009-9, Edital MGT/CNPq 02/2009) e Teoria Crítica, Racionalidades e Educação II, financiado pelo CNPq (Processos n. 572119/2008-9, 502892/2008-0, 308912/2007-1, 503353/2007-8).

Recebido em maio de 2010 Aprovado em setembro de 2010 
Sobre o domínio da natureza na filosofia da história de Theodor W. Adorno: uma questão para a educação

Tomando como referência fundamental o ensaio "A ideia de história natural" e o desdobramento de algumas de suas questões em Dialética do esclarecimento, mas também em outros textos que compõem o mesmo projeto crítico, o presente texto ocupa-se do tema da relação entre História e Natureza em Theodor W. Adorno. Para tanto, procura mostrar como o autor, em seu diálogo tenso com a tradição dialética, critica ambos os conceitos em sua aparência antitética, para então apresentar uma nova conceituação para segunda natureza. Ao final, mostra o entrelaçamento entre segunda natureza - como catástrofe-, técnica e educação, movimento que procura pôr em novos termos a assertiva adorniana de que Auschwitz não se repita.

Palavras-chave: Adorno, Theodor W.; educação e autonomia; filosofia da história

\section{On governing of nature in Adorno's philosophy of history: a topic for education}

The Idea of Natural History and some of its questions in Dialectic of Enlightenment, as well as in other essays of the same critical project, are sources of this paper, whose aim is to show results of a research about the relation between History and Nature by Theodor W. Adorno. It presents how the Author, an its hard dialog with dialectic tradition, criticizes both concepts in their antithetic appearance, to present a new concept of Second Nature. The sharing between 
Second Nature as Catastrophe, technique and education is thought to put in new terms Adorno's maxim that Auschwitz do not comeback.

Key words: Adorno, Theodor W.; education and autonomy; philosophy of history

\section{Sobre la dominación de la naturaleza en la filosofía de la historia de Theodor W. Adorno: una}

\section{cuestión para la educación}

Tomando en cuenta de manera fundamental el ensayo "La idea de historia natural" y el desarrollo de algunas se sus cuestiones en Dialéctica de la Ilustración, pero también en otros trabajos que componen el mismo proyecto crítico, el presente texto se dedica al tema de la relación entre Historia y Naturaleza en Theodor W. Adorno. Para tanto, procura mostrar como el autor, en su tenso diálogo con la tradición dialéctica, critica los dos conceptos en su carácter aparentemente antitético, para así presentar un nuevo concepto para segunda naturaleza. Al final, muestra el encuentro entre segunda naturaleza - como catástrofe -, técnica y educación, movimiento que propone en nueva clave la asertiva adorniana de que Auschwitz no se repita.

Palabras claves: Adorno, Theodor W.; educación y autonomía; filosofía de la historia 